\title{
ZUSES
}

\section{Aeromagnetic Map of Burney and the Surrounding Area, Northeastern California}

By Victoria E. Langenheim

Pamphlet to accompany

Open-File Report 2021-1006

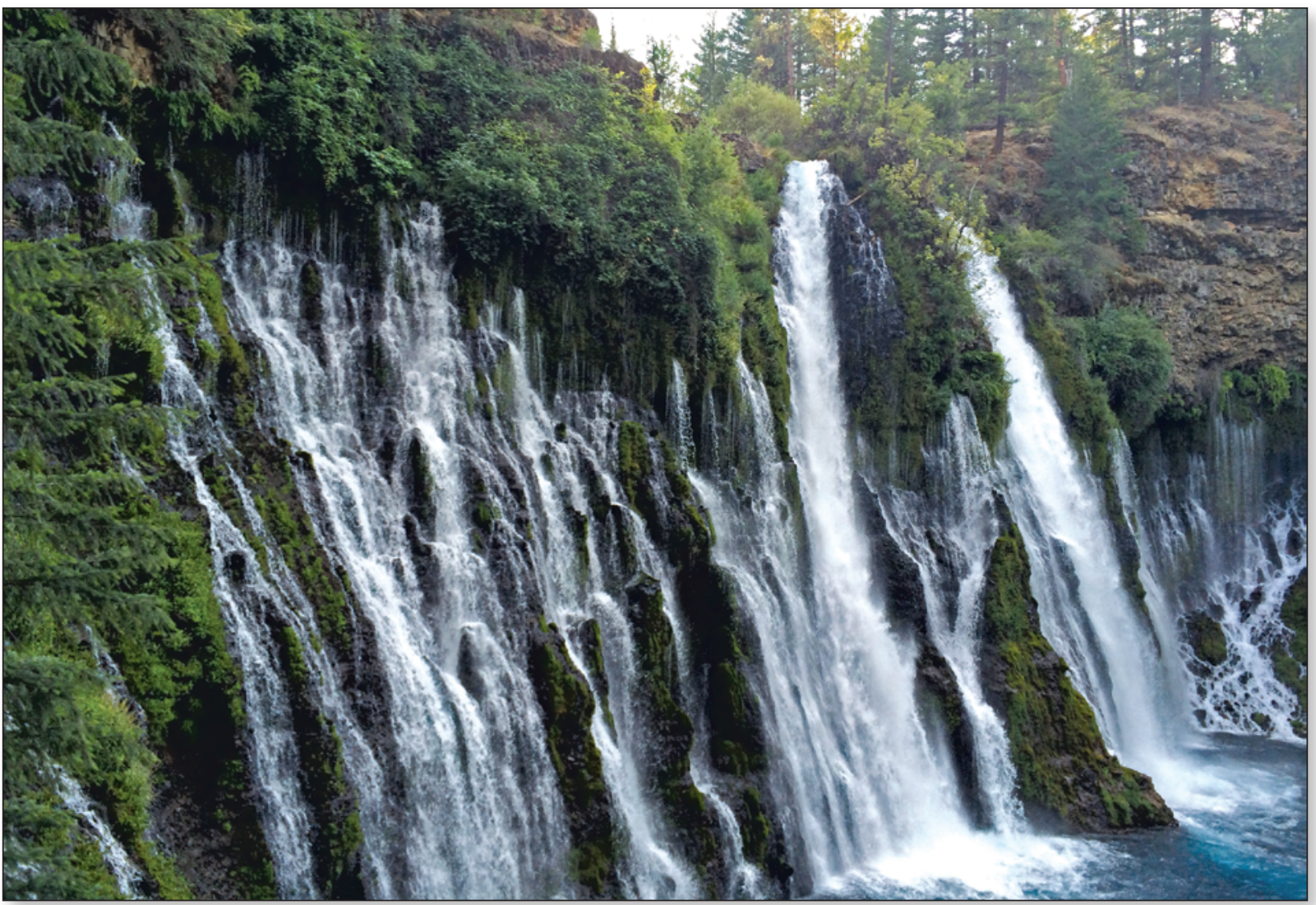

2021

U.S. Department of the Interior

U.S. Geological Survey 


\section{U.S. Geological Survey, Reston, Virginia: 2021}

For more information on the USGS — the Federal source for science about the Earth, its natural and living resources, natural hazards, and the environment-visit https://www.usgs.gov or call 1-888-ASK-USGS.

For an overview of USGS information products, including maps, imagery, and publications, visit https://store.usgs.gov.

Any use of trade, firm, or product names is for descriptive purposes only and does not imply endorsement by the U.S. Government.

Although this information product, for the most part, is in the public domain, it also may contain copyrighted materials as noted in the text. Permission to reproduce copyrighted items must be secured from the copyright owner.

Suggested citation:

Langenheim, V.E., 2021, Aeromagnetic map of Burney and the surrounding area, northeastern California: U.S.

Geological Survey Open-File Report 2021-1006, 8 p., 1 sheet, scale 1:250:000, https://doi.org/10.3133/ofr20211006.

Associated data for this publication:

Langenheim, V.E., 2019, Aeromagnetic data, grid data, and magnetization boundaries of a survey flown in the Burney region, northeastern California: U.S. Geological Survey data release, https://doi.org/10.5066/P9PUFYDD.

ISSN 2331-1258 (online)

Cover. View to west of Burney Falls. Photograph by Victoria Langenheim, July 30, 2015. 


\section{Acknowledgments}

The U.S. Geological Survey (USGS) National Cooperative Geologic Mapping program provided funding for this study. We thank Chris Evans and the rest of the crew at New-Sense Geophysics Ltd., who flew the survey and processed the data to total-field anomalies. Geoffrey Phelps and Donald Sweetkind (both USGS) provided constructive reviews and Aditya Navale provided a skilled edit. 


\section{Contents}

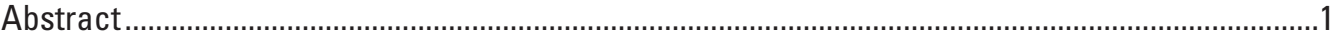

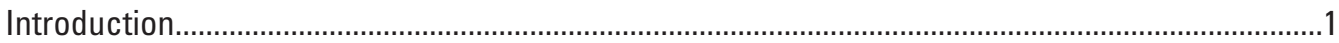

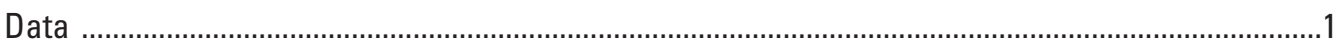

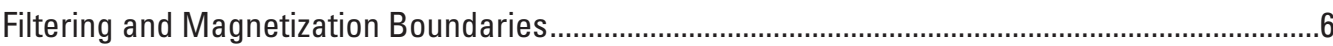

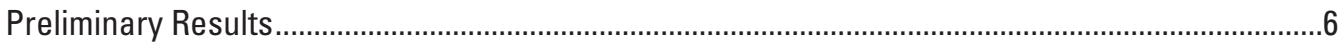

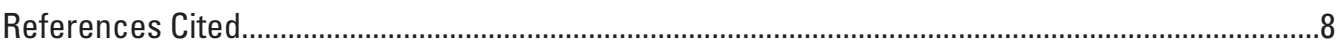

\section{Figures}

1. Simplified geologic map of area surrounding Burney, California, showing location and focal mechanism of M5.7 2013 Canyondam earthquake discussed in text

2. Map of area surrounding Burney, California, showing heights of magnetic sensor above ground surface measured by radar altimetry .............................................................. 3

3. Colored shaded-relief-aeromagnetic maps of area surrounding Burney, California .......4

4. Colored shaded-relief-aeromagnetic map of area surrounding Burney, California, filtered to enhance shallow sources...................................................................................

\section{Map Sheet}

1. Aeromagnetic Map of Burney and the Surrounding Area, Northeastern California

\section{Conversion Factors}

U.S. customary units to International System of Units

\begin{tabular}{llll}
\hline & Multiply & By & To obtain \\
\hline \multicolumn{4}{c}{ Length } \\
foot (ft) & 0.3048 & meter $(\mathrm{m})$ & \\
mile (mi) & 1.609 & kilometer $(\mathrm{km})$ & \\
\hline
\end{tabular}




\title{
Aeromagnetic Map of Burney and the Surrounding Area, Northeastern California
}

\author{
By Victoria E. Langenheim
}

\section{Abstract}

An aeromagnetic survey was conducted to improve understanding of the geology and structure in the area around Burney, northeastern California. The new data are a substantial improvement over existing data and reveal a prominent northnorthwest-trending magnetic grain that allows extension of mapped faults, delineation of plutons within the Mesozoic basement in the northern Sierra Nevada, and linear anomalies that limit the amount of strike-slip offset along various faults in the area.

\section{Introduction}

An aeromagnetic survey was conducted to promote further understanding of the geology and structure in the area of Burney in northeastern California, serving as a basis for geophysical interpretations and supporting geologic mapping, water-resource investigations, and volcanic- and seismic-hazard assessments. Although this area is sparsely populated, it contains some of the largest fresh-water springs in the United States (Meinzer, 1927). These springs contribute more than 50 percent of the perennial flow of the Pit River (Davisson and Rose, 2014), which is the largest tributary to Shasta Lake, which in turn is the largest reservoir in California. The Pit River is a substantial tributary of the Sacramento River, which is the largest and longest river in the state. The springs are hosted within the areally extensive volcanic rocks of mostly Tertiary and Quaternary age that blanket the survey area (fig. 1). The volcanic rocks are of tholeiitic and calc-alkaline affinity, reflecting the influence of Basin and Range extension and the Cascade Subduction Zone in this area (Clynne and Muffler, 2017). A couple of the flows are young, with flows of the Hat Creek Basalt and the basalt of Giant Crater dated at $24 \pm 6$ (thousand years ago) ka (Turrin and others, 2007; refined to $23.8 \pm 1.4$ ka by Rood and others, 2015) and 12,430 years before present (yr B.P.) (Donnelly-Nolan, 2010), respectively.

Seismic hazards are a concern in this area, as many of these Quaternary volcanic rocks, including the Hat Creek and Giant Crater flows, are offset by faults (fig. 1). Despite the area's low population, substantial infrastructure, including dams along the Pit River, are at risk. Although seismicity is generally dispersed, three historical earthquakes of about M6.2 in the late 1800s between Honey and Eagle Lakes produced widespread shaking (as much as Modified Mercalli Intensity (MM) 6; California Geological Survey, 2019). More recently, the 2013 M5.7 Canyondam earthquake near Lake Almanor (see fig. 1 for location) produced more damage than expected for the magnitude of the earthquake (Chapman and others, 2016).

This area is of interest to geologists because it lies at or near the intersection of multiple geologic provinces in northern California (Langenheim and others, 2016). The southern part of the aeromagnetic survey encompasses the northernmost exposures of the Sierra Nevada Batholith, which is part of the larger Sierra Nevada-Great Valley Block. The aeromagnetic survey covers the area east of Lassen Peak and Mount Shasta, located at the south end of the Cascade arc, and possibly across the poorly delineated south end of the Oregon Coast Block. The survey also extends across the westernmost part of the extensional Basin and Range geologic province. The Walker Lane, a zone of right-lateral shear east of the Sierra Nevada-Great Valley Block, encroaches into the area of the survey. The amount of right-lateral offset for the shear zone is unknown in this area, although faults in the northern Walker Lane have been suggested to have as much as 30 kilometers $(\mathrm{km})$ of displacement (Wesnousky, 2005; Faulds and others, 2005). A linear, uninterrupted aeromagnetic boundary in the eastern Klamath Mountains was used to preclude substantial, discrete right-lateral offsets along individual faults in that area (Langenheim and others, 2016), but the existing aeromagnetic data at that time lacked sufficient resolution to address that question in the main survey area.

\section{Data}

The aeromagnetic survey (fig. 1) was flown over parts of the McArthur, Burney, Eagle Lake, Susanville, Alturas, and Lake Almanor 1:100,000-scale quadrangles, totaling an area of approximately 13,190 square kilometers $\left(\mathrm{km}^{2}\right)$. Data-collection and -processing to total-field anomalies was carried out by New-Sense Geophysics Ltd., on contract to the U.S. Geological Survey. Total-field aeromagnetic data were collected along east-west-oriented flight lines, spaced 800 meters (m) apart, from October to December 2017. Distance between measurements along a flight line was about $8 \mathrm{~m}$. North-south-oriented tie lines 


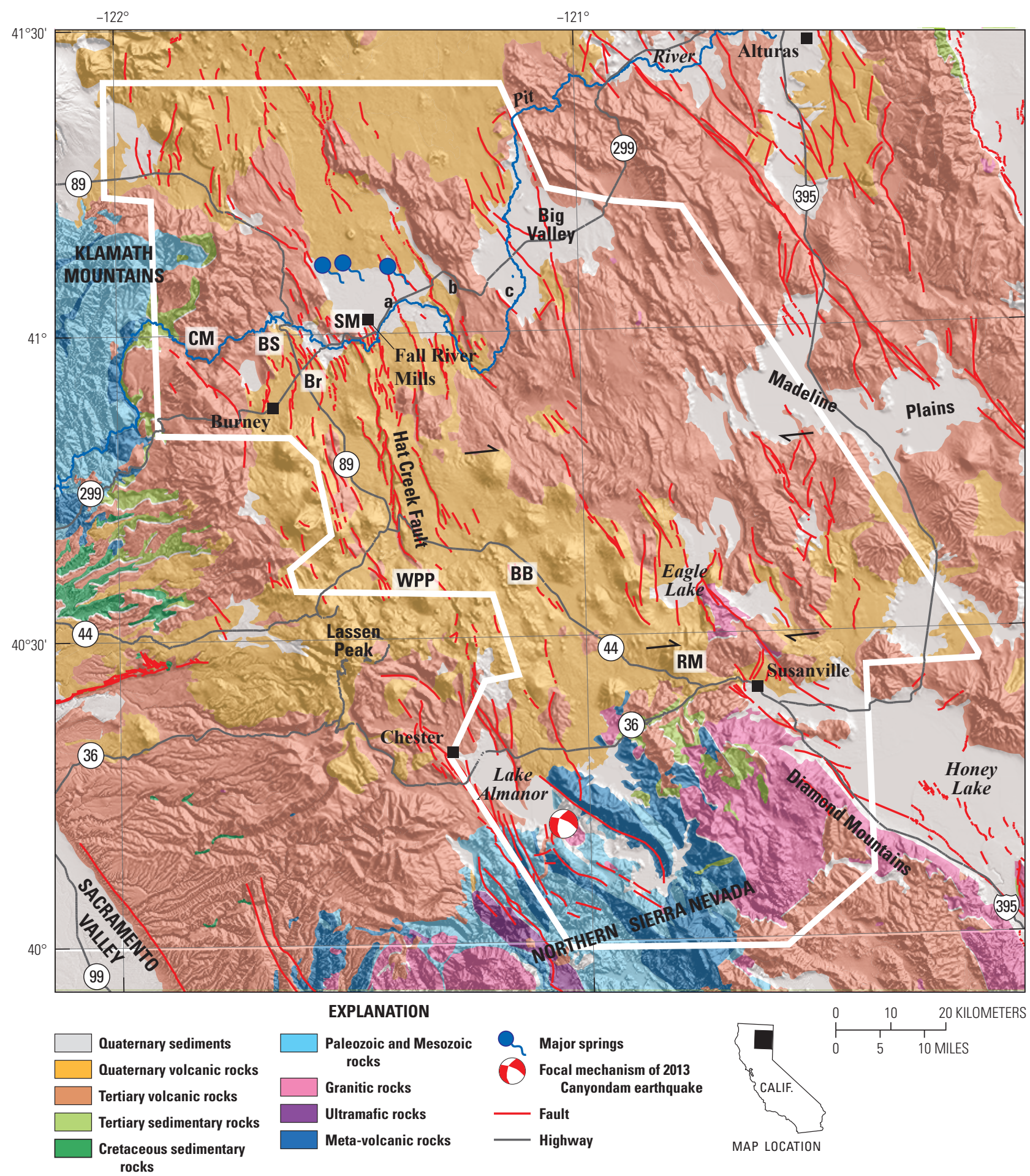

Figure 1. Simplified geologic map of area surrounding Burney, California (modified from Jennings and others, 2010), showing location and focal mechanism of M5.7 2013 Canyondam earthquake discussed in text. White line shows extent of aeromagnetic survey in this report. Red lines show faults (from U.S. Geological Survey and California Geological Survey, 2006). Offset pairs of half arrows show location of magnetic anomalies that are not disrupted by strike-slip offset discussed in text. Magnetic anomalies $(a, b, c)$ are discussed in text. Abbreviations: BB, Bogard Buttes; Br, Brush Mountain; BS, Burney Spring Mountain; CM, Chalk Mountain; RM, Roop Mountain; SM, Saddle Mountain; WPP, West Prospect Peak. Shaded-relief base, drainage, and roads from U.S. Geological Survey (2019).

were spaced 8,000 $\mathrm{m}$ apart. Although the specified survey height of the aircraft above the ground was $305 \mathrm{~m}$, the average height of the aircraft was approximately $430 \mathrm{~m}$ (fig. 2); locally, the aircraft was flown substantially higher than $305 \mathrm{~m}$ because of safety considerations due to steep slopes and inclement weather, most notably south of latitude $40^{\circ} 20^{\prime}$ (fig. 2). In this area, and in other areas adjacent to steep slopes, anomalies are smoother because of the higher flight elevation. 


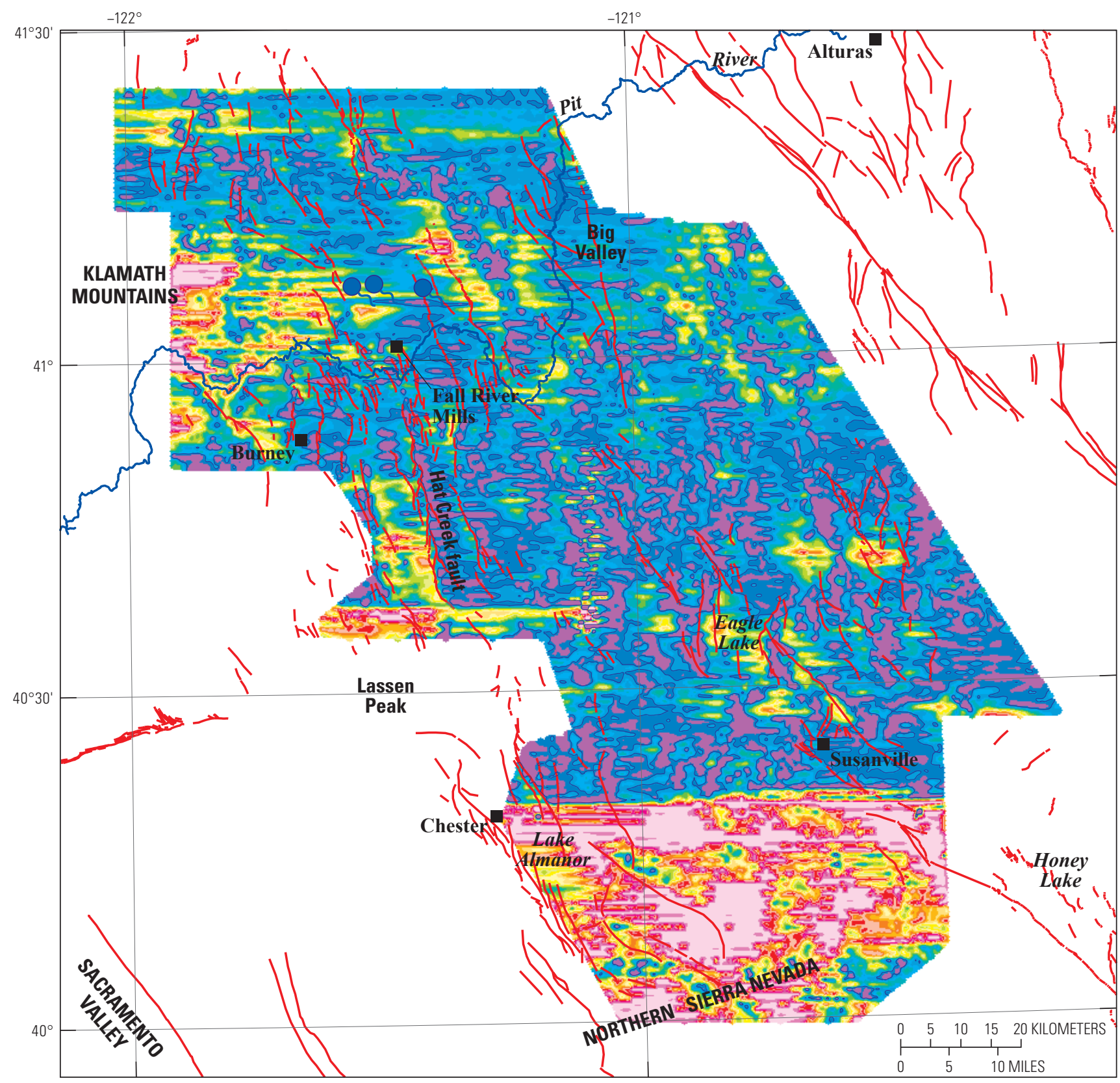

EXPLANATION

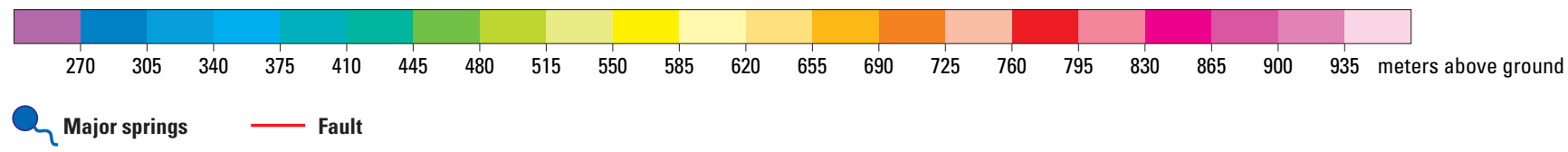

Figure 2. Map of area surrounding Burney, California, showing heights of magnetic sensor above ground surface measured by radar altimetry. Faults (red lines) are from U.S. Geological Survey and California Geological Survey (2006). Drainage from U.S. Geological Survey (2019).

The aeromagnetic measurements were collected using a cesium-vapor magnetometer (Scintrex CS-3) mounted in the tail boom of the aircraft. Measurements were corrected for the magnetic effect of the airplane using a triaxial fluxgate magnetometer. The measurements were adjusted so that the resulting magnetic field shown in the map and in figure 3 is relatively free of artifacts owing to the plane itself. Data were adjusted for tail sensor lag and diurnal field variations. The base magnetometer used to correct the diurnal field variations was a Scintrex CS-3 magnetometer located in magnetically quiet areas at the Fall River Mills and Susanville Municipal Airports (lat $41.024782^{\circ} \mathrm{N}$., long $121.427823^{\circ} \mathrm{W}$. and lat $40.375920^{\circ} \mathrm{N}$., long $120.574952^{\circ}$ W., respectively). Further processing included microleveling using the tie lines and correction for the Earth's 
$-122^{\circ}-121^{\circ}$
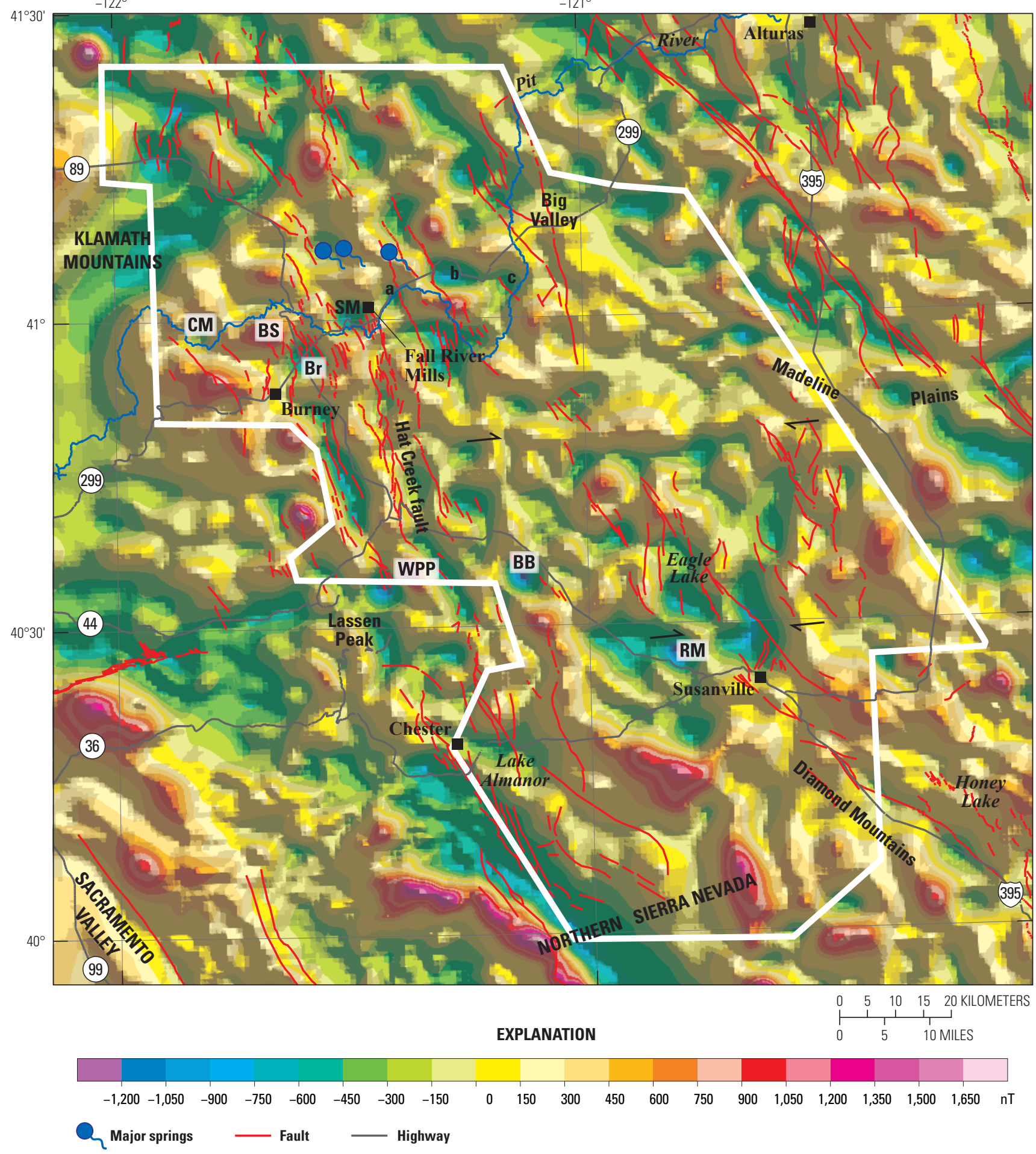

Figure 3. Colored shaded-relief-aeromagnetic maps of area surrounding Burney, California (nT, nanotesla[s]); shaded relief highlights the grain of magnetic anomalies. Thick white line shows extent of aeromagnetic survey in this report. Red lines show faults (from U.S. Geological Survey and California Geological Survey, 2006). Offset pairs of half arrows show location of magnetic anomalies that are not disrupted by strike-slip offset discussed in text. Magnetic anomalies (a, $b$, c) are discussed in text. Abbreviations: BB, Bogard Buttes; Br, Brush Mountain; BS, Burney Spring Mountain; CM, Chalk Mountain; RM, Roop Mountain; SM, Saddle Mountain; WPP, West Prospect Peak. Drainage and roads from U.S. Geological Survey (2019). A, Aeromagnetic map that is based on previous surveys (North American Magnetic Anomaly Group, 2002). $B$, Aeromagnetic map from data collected in this report and, in southwest corner (thin white outline), from Langenheim (2015). 


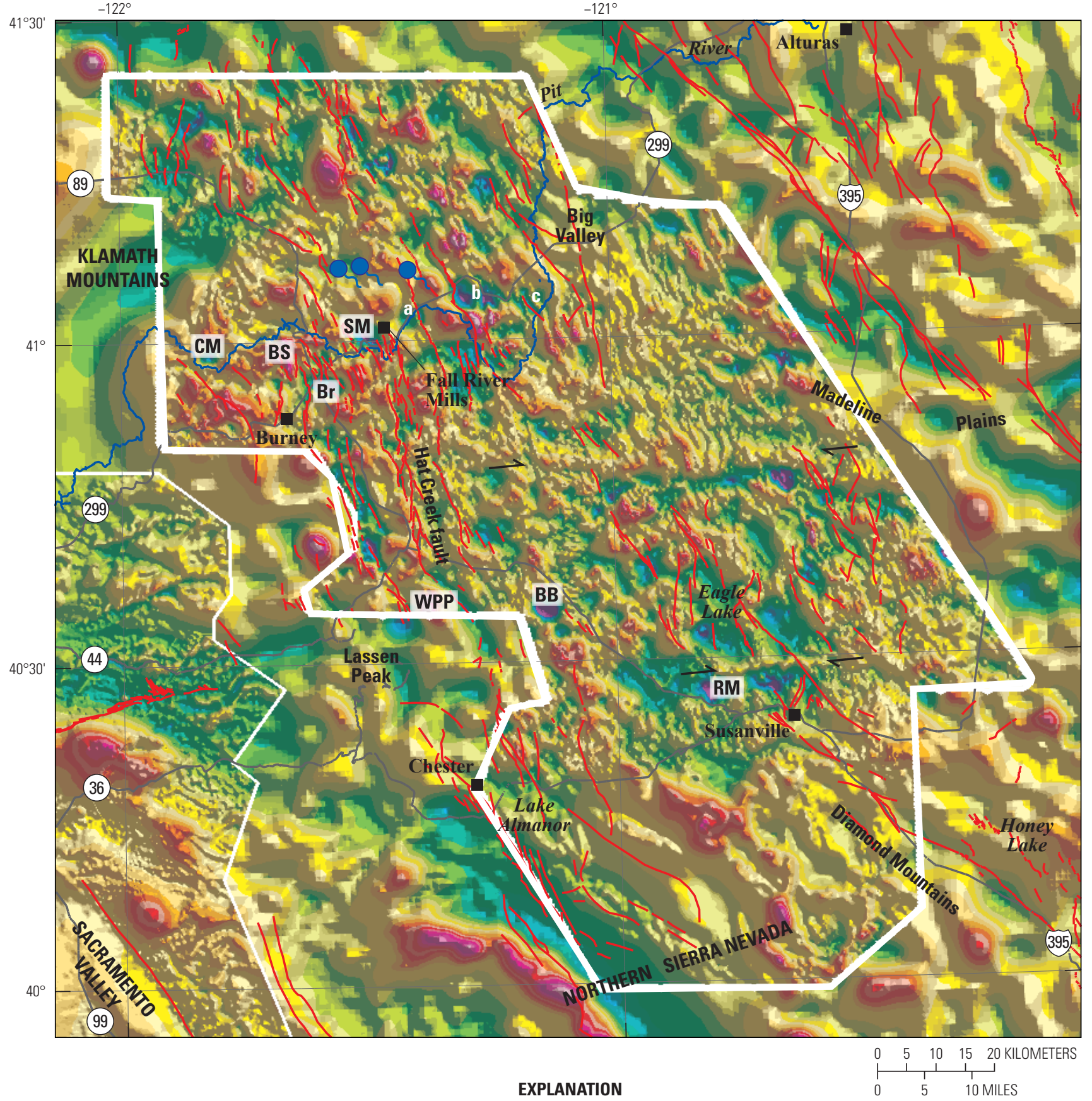

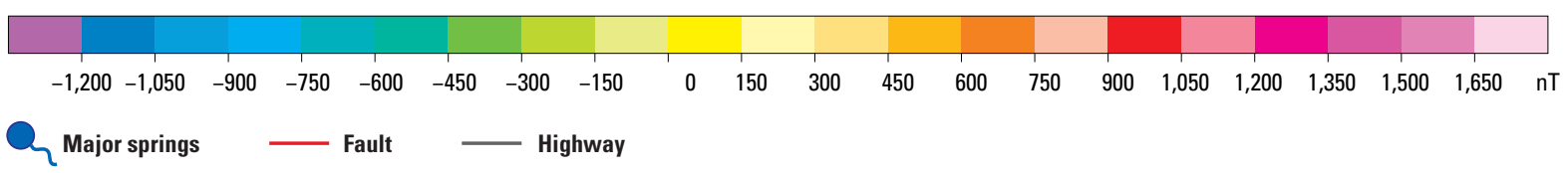

Figure 3. Continued

main magnetic field (International Geomagnetic Reference Field; see Langel, 1992), updated to the period during which the data were collected (October 3 to December 1, 2017).

The resulting data from the survey were transformed to a Universal Transverse Mercator projection (base latitude, $0^{\circ}$; central meridian, $123^{\circ} \mathrm{W}$.) and interpolated to a square grid, using a grid interval of $200 \mathrm{~m}$ and the principle of minimum curvature (Briggs, 1974). Accuracy of these survey data is 1 nanotesla (nT) or better.
The new data provide a considerable improvement on preexisting data (fig. $3 A$ ), which consisted of profiles flown 1.6 $\mathrm{km}$ apart at a constant altitude of 2,740 $\mathrm{m}$ (Couch and Gemperle, 1982). The dataset was compiled from information collected at too high of an elevation over valley areas to measure shortwavelength anomalies associated with near-surface or exposed sources, such as volcanic rocks. Although aeromagnetic profiles were flown closer to the ground $(120 \mathrm{~m}$ ) by the National Uranium 
Resource Evaluation Program (Hill and others, 2009), these lines were flown too far apart $(4,800 \mathrm{~m})$ to effectively map the magnetic field between the lines. The map (on map sheet; see also, fig. $3 B$ ) reveals substantially more short-wavelength magnetic anomalies, which are associated with Cenozoic volcanic rocks.

\section{Filtering and Magnetization Boundaries}

To help delineate structural trends and gradients expressed in the magnetic fields, a computer algorithm was used to locate the maximum horizontal gradient (Cordell and Grauch, 1985; Blakely and Simpson, 1986). Faults beneath valley areas or thin basalt flows can be mapped using horizontal gradients in the magnetic fields, particularly where Cenozoic volcanic rocks are offset by faults. Magnetization boundaries were calculated on a filtered version of the magnetic field to isolate anomalies caused by shallow sources (Blakely, 1995). First, the magnetic field was upward-continued in elevation by $100 \mathrm{~m}$ and subtracted from the original magnetic field. This procedure emphasizes those parts of the magnetic field that are caused by the shallow (generally, in the uppermost $1 \mathrm{~km}$ ) parts of the magnetic bodies, which are most closely related to the mapped geology. This residual magnetic field emphasizes more subtle features (fig. 4), which may not be readily apparent in the unfiltered aeromagnetic map. Second, the resulting residual aeromagnetic field was mathematically transformed into magnetic potential anomalies (Baranov, 1957); this procedure effectively converts the magnetic field to the equivalent "gravity" field that would be produced if all magnetic material were replaced by proportionately dense material. This procedure also removes the dipolar effect of the Earth's magnetic field and shifts the anomalies over their sources, using an inclination and declination of the main magnetic field of $64^{\circ}$ and $15^{\circ}$, respectively. The horizontal gradient of the magnetic potential field was then calculated everywhere by numerical differentiation. The locations of the locally steepest horizontal gradient (see map sheet) were determined by numerically searching for maxima in the horizontal gradient grid (Blakely and Simpson, 1986). Gradient maxima are present approximately over steeply dipping contacts that separate rocks of contrasting magnetizations. For moderate to steep dips $\left(45^{\circ}\right.$ to vertical), the horizontal displacement of a gradient maximum from the top edge of an offset horizontal layer is always less than or equal to the depth to the top of the source (Grauch and Cordell, 1987).

\section{Preliminary Results}

Magnetic anomalies are generally caused by magnetitebearing rocks, which are often igneous. Much of the area is characterized by short-wavelength, narrow, north-northwesttrending magnetic anomalies (parallel to the structural and topographic grain) that are present over extensive areas of volcanic rocks. The structural grain is interrupted locally by prominent semicircular magnetic highs and lows. Several of these highs and lows are ascribed to young lava cones or shield volcanoes, such as Bogard Buttes, West Prospect Peak, Brush Mountain,
Burney Springs Mountain, Chalk Mountain, and Saddle Mountain (figs. 1 and 3); the magnetic polarity of the rocks that form these volcanoes determines whether the edifice is marked by a positive or negative anomaly and may help constrain the age of the feature (Langenheim and others, 2016). Another semicircular low at Roop Mountain (figs. 1, 3) is consistent with a nearby age of $3.9 \pm 0.2$ millions of years ago (Ma) (Grose and others, 2014). However, a prominent volcano does not always correspond to a simple magnetic high or low, which perhaps is indicative of complexity within the volcanic stratigraphy that makes up the volcano.

These semicircular anomalies are considerably sharper in the new data. For example, the magnetic low associated with Brushy Mountain is more elongate; furthermore, the filtered data reveal a very small magnetic high within the low. This small magnetic high, which was not discernible in the earlier, lower resolution data, supports the interpretation from paleomagnetic data that the bulk of the volcano is reversed polarity, except for the top of the edifice, which consists of normal-polarity flows.

The new data also reveal that some of these semicircular anomalies are, in fact, more complicated; in this case, they are bisected by narrow, linear magnetic highs (see, for example, anomaly b in figs. 3, 4, and Langenheim and others, 2016). The narrow anomaly is likely fault related and may be related to a short, mapped Quaternary fault a few kilometers to the south. Linear, narrow magnetic anomalies are often associated with mapped Quaternary faults, most notably along the Hat Creek Fault. Similar linear magnetic highs across Fall River Valley can be interpreted as faults concealed beneath the young sedimentary deposits.

Sedimentary rocks are, in general, weakly magnetic. A relatively smooth magnetic field coincides with areas of sedimentary cover, such as Fall River Valley and Big Valley and, to some extent, the Madeline Plains (figs. 1, 3B). Big and Fall River Valleys coincide with gravity lows that have amplitudes of 20 milligals (mGal) (Langenheim and others, 2016), indicating that these areas are underlain by thick sedimentary fill. This is consistent with the attenuation of the magnetic anomalies in these areas because the magnetic source rocks are concealed by thick, nonmagnetic sedimentary fill. A gravity low of about $10 \mathrm{mGal}$ coincides with part of the Madeline Plains, although the measurements are widely spaced and, thus, the amplitude and areal extent of the gravity anomaly are poorly constrained. Smoother magnetic anomalies also coincide with extensive outcrops of Paleozoic and Mesozoic metasedimentary rocks in the northern Sierra Nevada and eastern Klamath Mountains, although the greater height of the survey above both areas also contributes to the smoothing and broadening of magnetic anomalies. As in the eastern Klamath Mountains, magnetic highs in the northern Sierra Nevada generally coincide with Mesozoic metavolcanic rocks. Granitic rocks in the Diamond Mountains are associated with broad magnetic highs that are encircled by narrow magnetic highs of even greater amplitude. These narrow highs may have origins similar to the intense magnetic highs that encircle other Sierra Nevada Plutons, such as the Bald Rock Pluton about $60 \mathrm{~km}$ to the southwest, attributed to contact metamorphism and intermingling of magnetic country rock. The semicircular rings suggest that at least two plutons are present within the Diamond Mountains. 


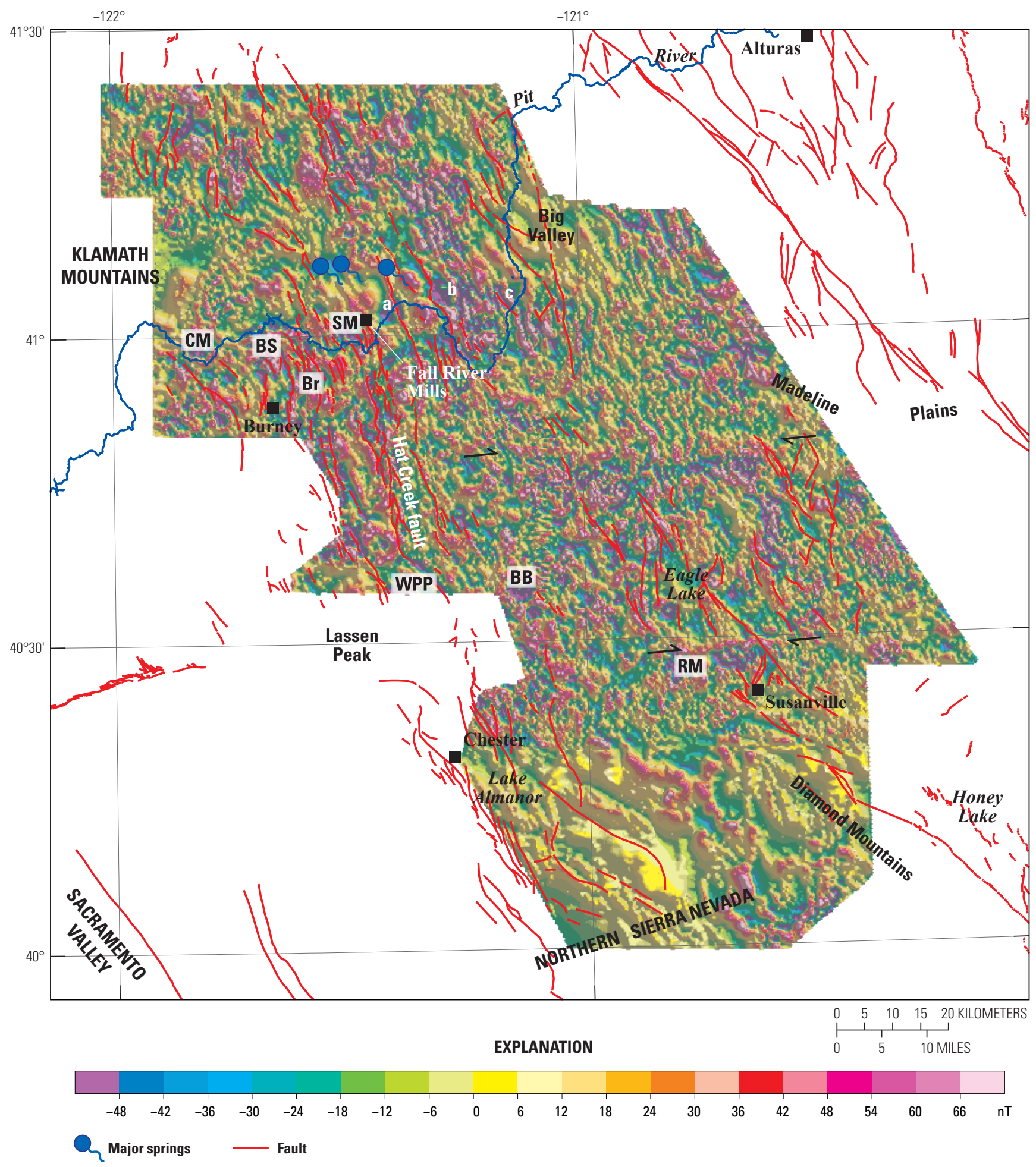

Figure 4. Colored shaded-relief-aeromagnetic map of area surrounding Burney, California, filtered to enhance shallow sources (nT, nanotesla[s]). Red lines show faults (from U.S. Geological Survey and California Geological Survey, 2006). Offset pairs of half arrows show location of magnetic anomalies that are not disrupted by strike-slip offset discussed in text. Magnetic anomalies (a, b, c) are discussed in text. Abbreviations: BB, Bogard Buttes; Br, Brush Mountain; BS, Burney Spring Mountain; CM, Chalk Mountain; RM, Roop Mountain; SM, Saddle Mountain; WPP, West Prospect Peak. Drainage from U.S. Geological Survey (2019). 
The new data also reveal a couple of long, linear, eastwest-trending magnetic anomalies that do not coincide with topographic and geologic features (figs. 1, 3, 4). The southernmost of these is not evident in the older data. These anomalies cross several mapped Quaternary faults without showing substantial $(>2 \mathrm{~km}$ ) apparent right-lateral offset. A possible exception is the fault zone that cuts across the western part of the Madeline Plains, where a magnetic high appears to be offset by about $5 \mathrm{~km}$.

\section{References Cited}

Baranov, V.I., 1957, A new method for interpretation of aeromagnetic maps - Pseudo-gravimetric anomalies: Geophysics, v. 22, p. 359-383.

Blakely, R.J., 1995, Potential theory in gravity and magnetic applications: Cambridge, England, Cambridge University Press, $441 \mathrm{p}$.

Blakely, R.J., and Simpson, R.W., 1986, Approximating edges of source bodies from magnetic or gravity anomalies: Geophysics, v. 51, p. 1494-1498.

Briggs, I.C., 1974, Machine contouring using minimum curvature: Geophysics, v. 39, p. 39-48.

California Geological Survey, 2019, Historic Earthquake Online Database: California Geological Survey website, accessed July 2, 2017, at https://maps.conservation.ca.gov/cgs/historicearthquakes/.

Chapman, K., Gold, M.B., Boatwright, J., Sipe, J., Quitoriano, V., Dreger, D., and Hardebeck, J., 2016, Faulting, damage, and intensity in the Canyondam earthquake of May 23, 2013: U.S. Geological Survey Open-File Report 2016-1145, 49 p., accessed February 20, 2019 at https://doi.org/10.3133/ ofr20161145.

Clynne, M.A., and Muffler, L.J.P., 2017, Geologic field-trip guide to the Lassen segment of the Cascades Arc, northern California: U.S. Geological Survey Scientific Investigations Report 2017-5022-K2, 65 p., accessed June 6, 2019 at https://doi. org/10.3133/sir20175022K2.

Cordell, L., and Grauch, V.J.S., 1985, Mapping basement magnetization zones from aeromagnetic data in the San Juan Basin, New Mexico, in Hinze, W.J., ed., The utility of regional gravity and magnetic anomaly maps: Tulsa, Okla., Society of Exploration Geophysicists, p. 181-197.

Couch, R., and Gemperle, M., 1982, Aeromagnetic measurements in the Cascade Range and Modoc Plateau of northern California-Report on work done from June 1, 1980, to November 30, 1980: U.S. Geological Survey Open-File Report 82-932, 23 p.

Davisson, M.L., and Rose, T.P., 2014, Recharge and flow in the Medicine Lake volcano-Fall River Springs groundwater basin, California: Environmental Forensics, v. 15, p. 66-77.

Donnelly-Nolan, J.M., 2010, Geologic map of Medicine Lake volcano, northern California: U.S. Geological Survey Scientific Investigations Map 2927, 2 sheets, scale 1:50.000, pamphlet 48 p., accessed May 15, 2019 at https://doi.org/10.3133/sim2927.

Faulds, J.E., Henry, C.D., and Hinz, N.H., 2005, Kinematics of the northern Walker Lane-An incipient transform fault along the Pacific-North American plate boundary: Geology, v. 6, p. 505-508.

Grauch, V.J.S., and Cordell, L., 1987, Limitations of determining density or magnetic boundaries from the horizontal gradient of gravity or pseudogravity data: Geophysics, v. 52, p. 118-121.

Grose, T.L.T., Saucedo, G.J., and Wagner, D.L., 2014, Preliminary geologic map of the Susanville $30^{\prime} \times 60^{\prime}$ quadrangle, California: California Geological Survey, Preliminary Geologic Map, scale $1: 100,000,25 \mathrm{p}$.

Hill, P.L., Kucks, R.P., and Ravat, D., 2009, Aeromagnetic and aeroradiometric data for the conterminous United States and Alaska from the National Uranium Resource Evaluation Program of the U.S. Department of Energy: U.S. Geological Survey Open-File Report 2009-1129, accessed May 22, 2015, at https:// doi.org/10.3133/ofr20091129.

Jennings, C.W., Gutierrez, C., Bryant, W., Saucedo, G., and Wills, C., 2010, Geologic map of California: California Geological Survey, California Geological Survey Data Map 2, scale $1: 750,000$.

Langel, R.A., 1992, International geomagnetic reference fieldThe sixth generation: Journal of Geomagnetism and Geoelectricity, v. 44, p. 679-707.

Langenheim, V.E., 2015, Aeromagnetic survey map of Sacramento Valley, California: U.S. Geological Survey Open-File Report 2015-1186, scale 1:400,000, accessed January 15, 2016 at https://doi.org/10.3133/ofr20151186.

Langenheim, V.E., Jachens, R.C., Muffler, L.P.J., and Clynne, M.A., 2016, Implications for the structure of the Hat Creek graben and transfer of right-lateral shear from the Walker Lane north of Lassen Peak, northern California, from gravity and magnetic anomalies: Geosphere, v. 12, p. 790-808.

Meinzer, O.E., 1927, Large springs in the United States: U.S. Geological Survey Water-Supply Paper 557, 94 p.

North American Magnetic Anomaly Group, 2002, Digital data grids for the magnetic anomaly map of North America: U.S. Geological Survey Open-File Report 02-0414, accessed December 15, 2020 at https://pubs.usgs.gov/of/2002/ofr-02-414.

Rood, D., Amidon, W., McKeon, R., Baldwin, J., Gray, B., Page, W., and Farley, K., 2015, Paleoseismic assessment of the Hat Creek fault using cosmogenic He-3 surface exposure dating in basalt, northeastern California-A proof of concept study [abs.]: San Francisco, Calif., December 14-18, 2015, American Geophysical Union, Fall Meeting, abstract T42A-01.

Turrin, B.D., Muffler, L.J.P., Clynne, M.A., and Champion, D.E., 2007, Robust $24 \pm 6 \mathrm{ka}{ }^{40} \mathrm{Ar} /{ }^{39} \mathrm{Ar}$ age of a low-potassium tholeiitic basalt in the Lassen region of NE California: Quaternary Research, v. 68, p. 96-110.

U.S. Geological Survey, 2019, The National Map, accessed February 15, 2019, at https://viewer.nationalmap.gov/basic.

U.S. Geological Survey and California Geological Survey, 2006, Quaternary fault and fold database for the United States: U.S. Geological Survey website, accessed February 22, 2012, at https://doi.org/10.5066/F7S75FJM.

Wesnousky, S.G., 2005, The San Andreas and Walker Lane fault systems, western North America-Transpression, transtension, cumulative slip and the structural evolution of a major transform plate boundary: Journal of Structural Geology, v. 27, p. 1505-1512. 